http://jmscr.igmpublication.org/home/

ISSN (e)-2347-176x ISSN (p) 2455-0450

crossref DOI: https://dx.doi.org/10.18535/jmscr/v7i10.163

Journal Of Medical Science And Clinical Research

\title{
A Clinico-Pathological Study of Soft Tissue Sarcomas
}

\author{
Authors \\ Dr P. Mythili, MS ${ }^{1}$, Dr Samana Vidya Sagar ${ }^{2}$, Dr S. Karuna Reddy ${ }^{3}$, \\ Dr M. Yesuprasad ${ }^{4}$ \\ ${ }^{1}$ Chief Surgeon, Department of General Surgery, AMC, Vizag \\ ${ }^{2,3,4}$ Post Graduate, Department of General Surgery, AMC, Vizag
}

\section{Introduction}

- Soft Tissue Sarcomas

They constitute $1 \%$ of adult malignancies.

- They are common in middle age and males.

Common sites of occurrence are in the lower limb, upperlimb, retroperitoneum, viscera, and trunk.

- They have rapid growth and early blood spread.

- They are relatively more aggressive compared to carcinomas.

- Treatment is surgery followed by adjuvant radiotherapy and chemotherapy.

\section{Aims and Objectives}

To study

The age of incidence

- Sex preponderance

- Clinical presentation regarding the anatomical site of occurrence

- Various histo-pathological varieties of sarcomas

- Recurrence after treatment with wide local excision and adjuvant radiotherapy.

\section{Materials and Methods}

A prospective study was made from June 2017 to June 2019 on 20 patients who presented to the Department of General Surgery, Andhra medical college/ King George hospital, Visakhapatnam with signs and symptoms of soft tissue sarcoma.

- The Study is based on clinical examination, radiological findings and histopathological examination and wide local excision, adjuvant radiotherapy, and follow up.

\section{Inclusion Criteria}

> 20 cases operated are included

- Cases not having metastasis.

- Cases which are in stage 1,2,3

- All cases are operated with wide excision and later adjuvant radiotherapy given based on the grade of the tumor.

- Resectable tumors.

- Cases with a minimum follow up of 6 months.

\section{Exclusion Criteria}

$>$ Cases with stage4 disease and distant metastasis.

$>$ Cases not in follow up or lost follow up in between. 


\section{Results}

- Twenty cases of soft tissue sarcomas included in the study.

- All cases are middle-aged (25-50 years).

- There is no metastasis in any case.

- Wide local excision is done for all cases followed by adjuvant radiotherapy and followed up for six months during the study.

- Two subjects are observed to have Recurrence in Follow up.

\section{Patient Data}

\begin{tabular}{|c|c|}
\hline CHARACTERISTICS & NUMBER \\
\hline TOTAL PATIENTS(M,F) & $20(18,2)$ \\
\hline AGE(30-50YEARS) & 20 \\
\hline $\begin{array}{l}\text { ANATOMICAL STTE: } \\
\text { LOWER LIMBS } \\
\text { UPPERLIMB S } \\
\text { TRUNK } \\
\text { HEAD AND NECK }\end{array}$ & $\begin{array}{l}10 \\
4 \\
4 \\
2\end{array}$ \\
\hline PAST HISTORY OF SIMILAR SWELLING & 0 \\
\hline $\begin{array}{l}\text { HISTOPATHOLOGY VARIETY: } \\
\text { MALIGNANT FIBROUS HISTIOCY TOMAS } \\
\text { LIPOSARCOMA } \\
\text { PERIPHERAL NERVE SHEATH TUMOUR } \\
\text { SYNOVIAL CELL CARCINOMA } \\
\text { RHABDOMYOSARCOMA }\end{array}$ & $\begin{array}{l}8 \\
6 \\
3 \\
2 \\
2 \\
1\end{array}$ \\
\hline RECURRENCE & $\begin{array}{l}\text { 2(both are } \\
\text { males) }\end{array}$ \\
\hline
\end{tabular}

\section{Sex Distribution}

Out of 20 Cases, All Are Middle-Aged
MALES ARE 18 AND FEMALES ARE 2 CASES

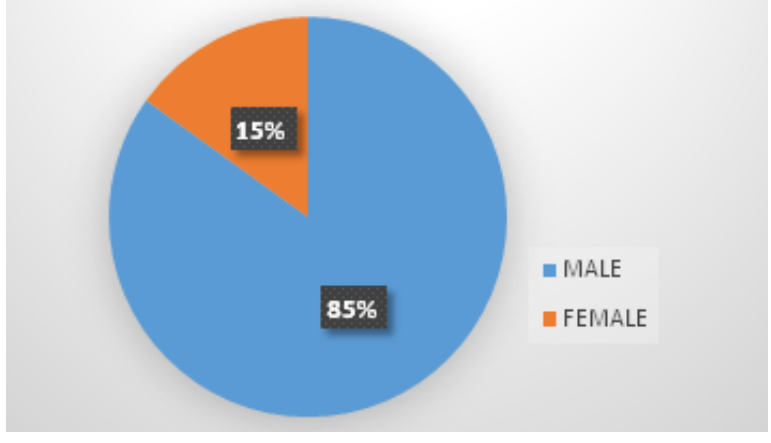

\section{Incidence based on anatomical site}

\begin{tabular}{|l|l|}
\hline HISTO-PATHOLOGICAL VARIETY & NUMBER OF CASES(\%) \\
\hline MALIGNANT FIBROUS HISTIOCYTOMA & $8 \mathrm{CASES}(40 \%)$ \\
\hline LIPOSARCOMA & $6 \mathrm{CASES}(30 \%)$ \\
\hline PERIPHERAL NERVE SHEATH TUMOUR & 3 CASES $(15 \%)$ \\
\hline SYNOVIAL CELL SARCOMA & $2 \mathrm{CASES}(10 \%)$ \\
\hline DERMATOFIBROSARCOMA & 1 CASE $(5 \%)$ \\
\hline
\end{tabular}

\section{Incidence of various histopathological types}

\begin{tabular}{|l|l|}
\hline HISTO-PATHOLOGICAL VARIETY & NUMBER OF CASES(\%) \\
\hline MALIGNANT FIBROUS HISTIOCYTOMA & $8 \mathrm{CASES}(40 \%)$ \\
\hline LIPOSARCOMA & $6 \mathrm{CASES}(30 \%)$ \\
\hline PERIPHERAL NERVE SHEATH TUMOUR & $3 \mathrm{CASES}(15 \%)$ \\
\hline SYNOVIAL CELL SARCOMA & $2 \mathrm{CASES}(10 \%)$ \\
\hline DERMATOFIBROSARCOMA & $1 \mathrm{CASE}(5 \%)$ \\
\hline
\end{tabular}

Cases with past history of similar swelling are zero.

- Cases with recurrence are two in number during the period of study and, both the cases are malignant fibrous histiocytomas.

\section{Case 1:}

A 46-year-old male with soft tissue tumor over back of chest below axilla-HPE - MALIGNANT FIBROUS HISTIOCYTOMA

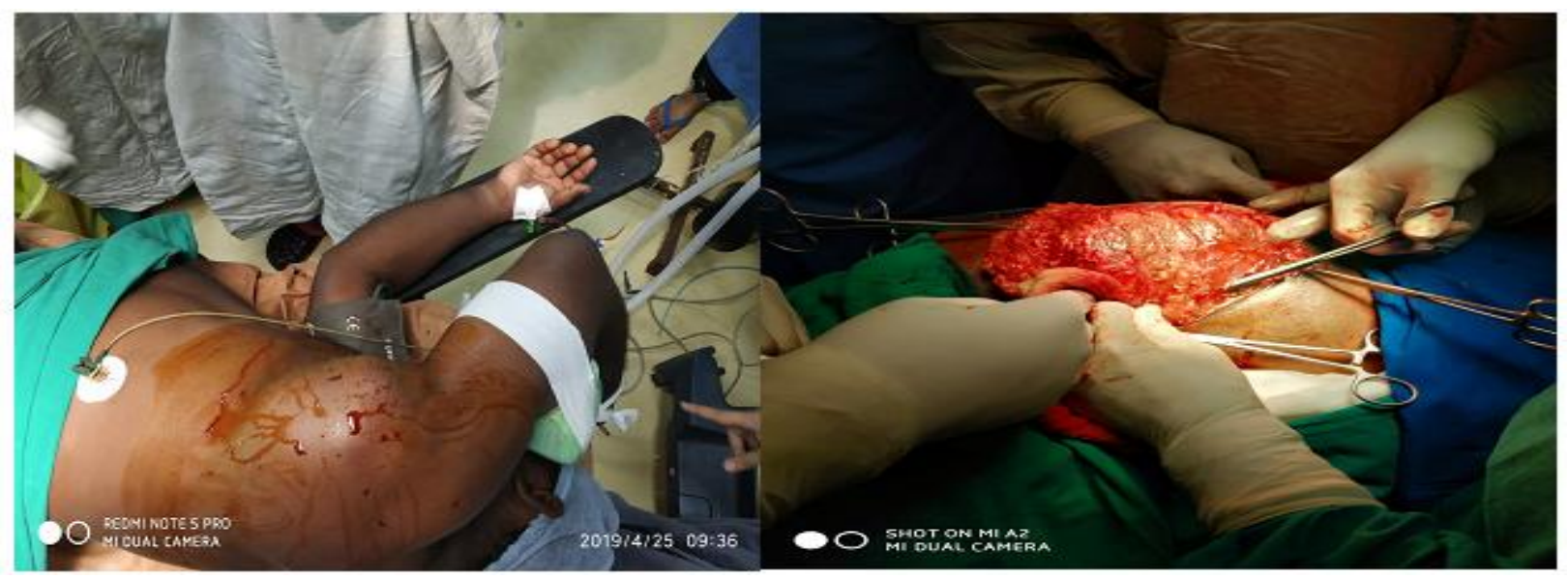




\section{JMSCR Vol||07||Issue $\|10\|$ Page 947-953||October}

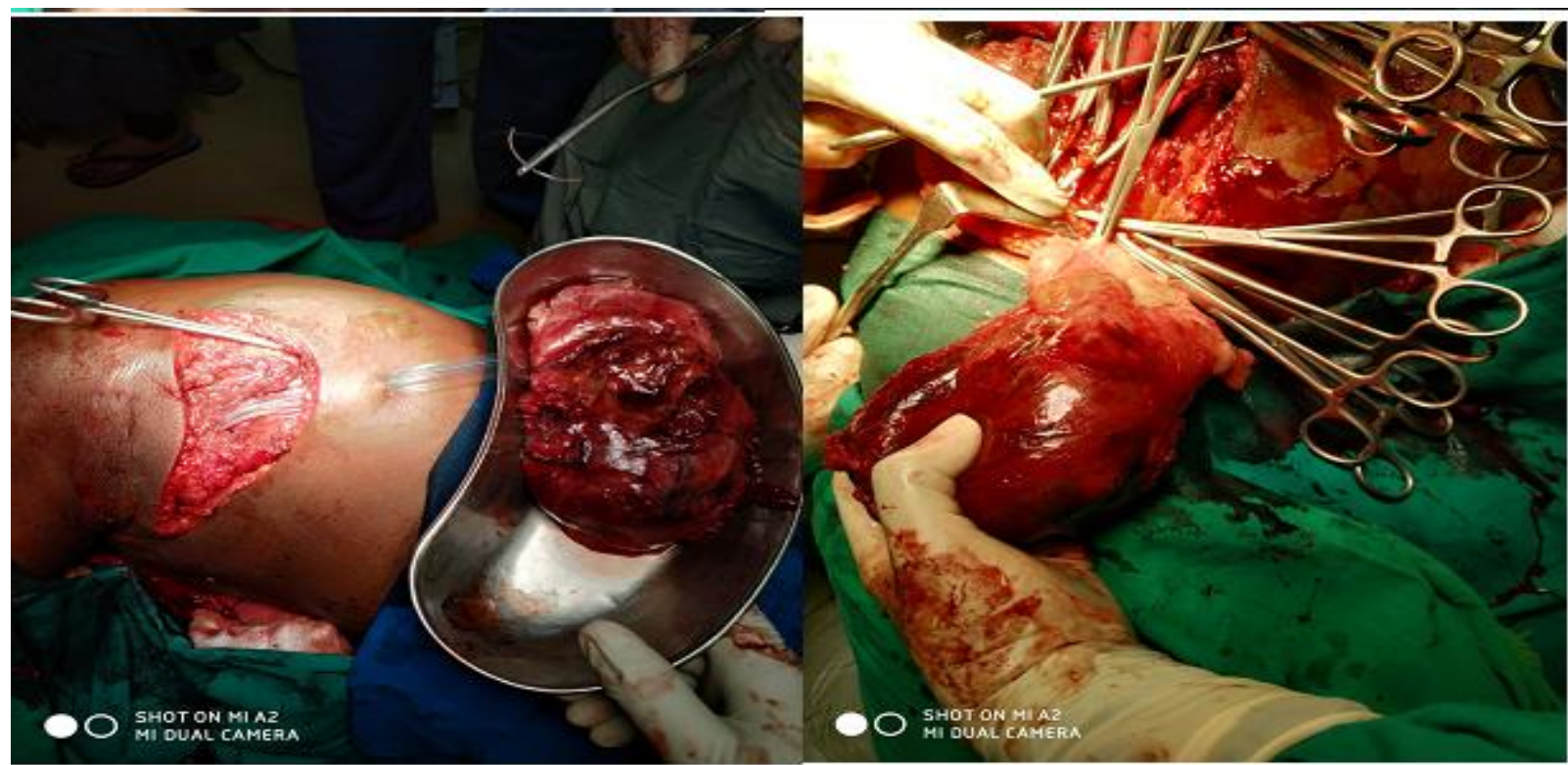

\section{Case 2}

A 42-Year-old male with soft tissue tumor over right loin- HPE - LIPOSARCOMA
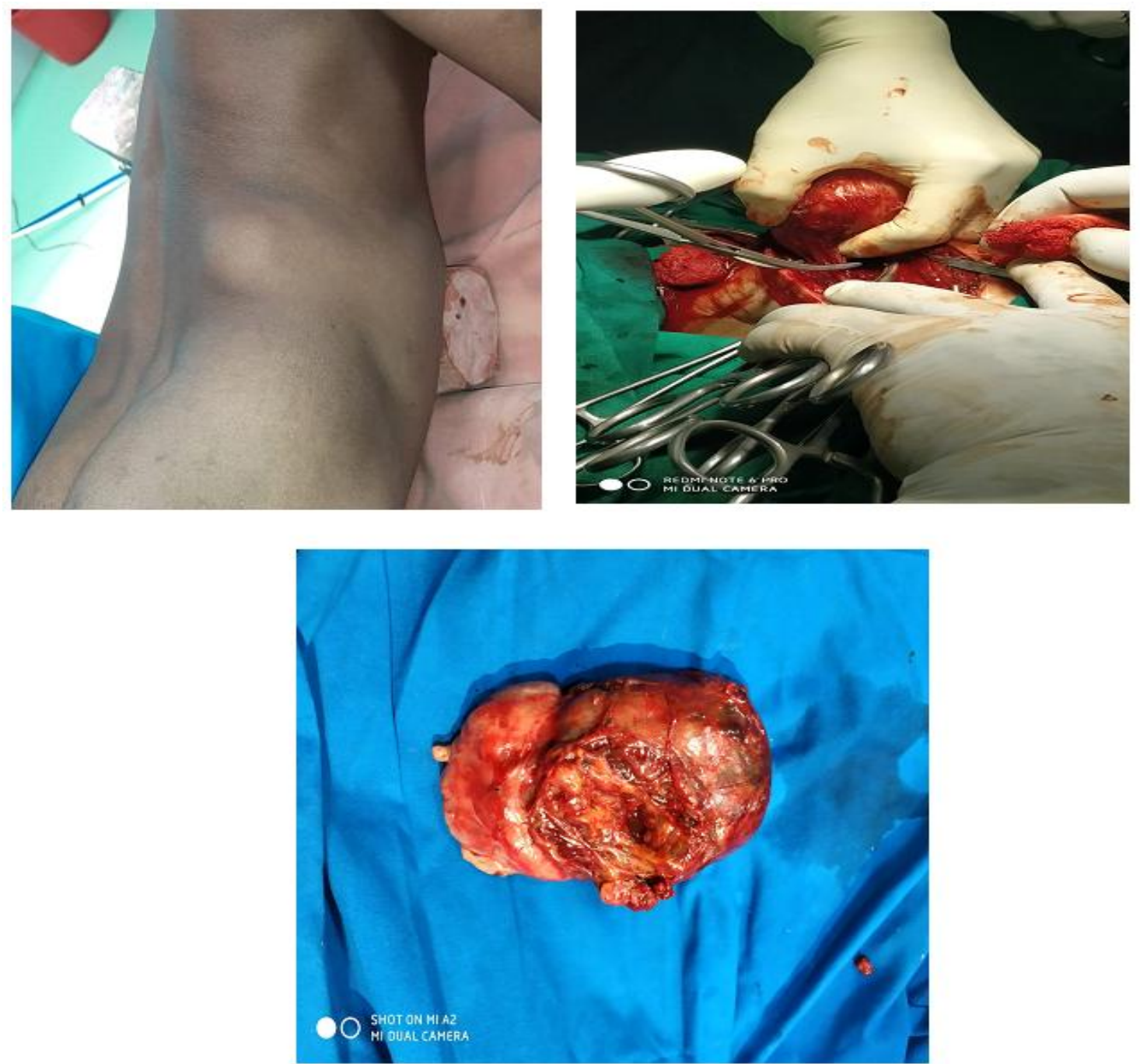


\section{Case 3}

A 42 year patient with soft tissue sarcoma over the back- HPE is low grade malignant fibrous histiocytoma
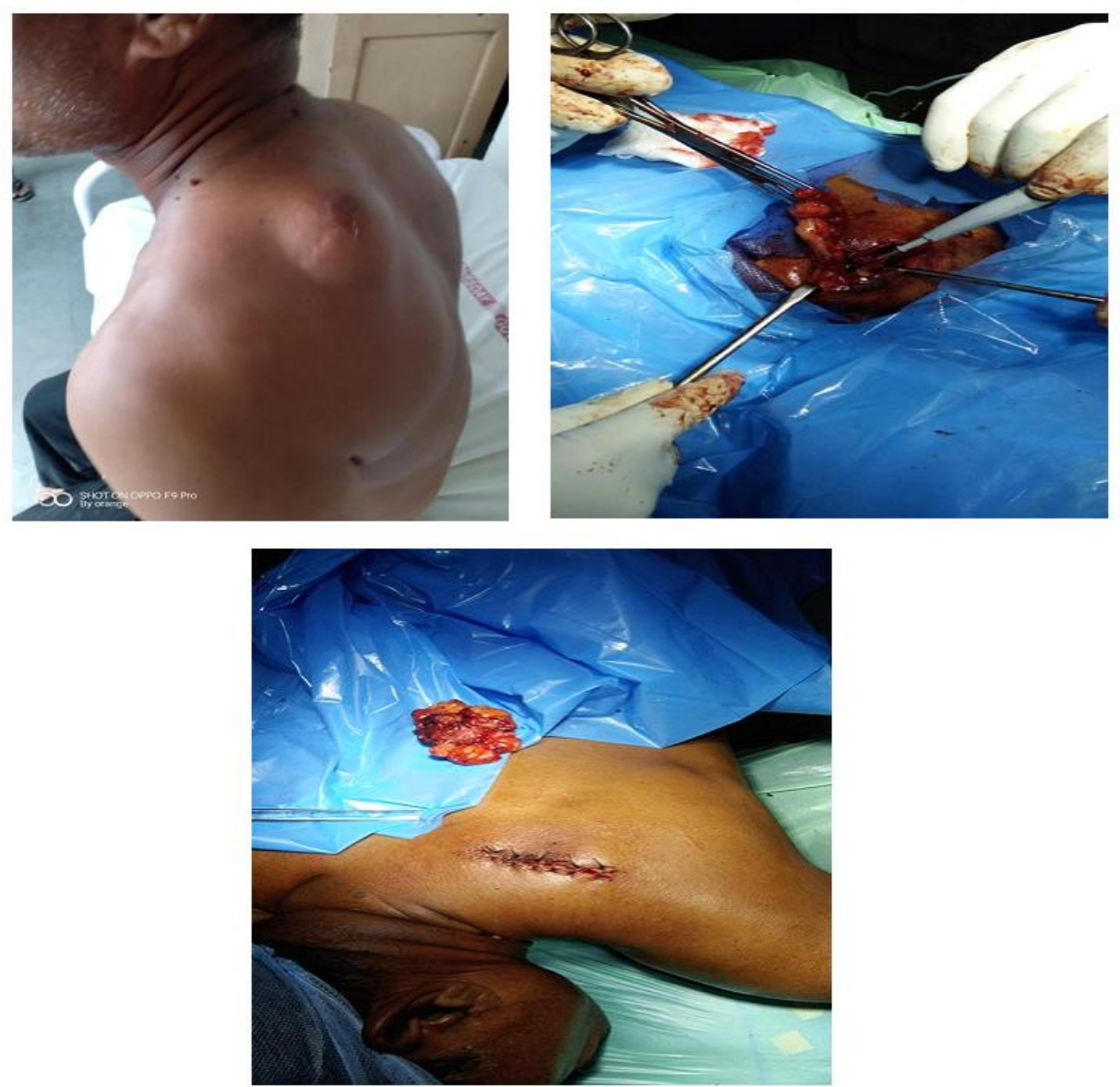

\section{Case 4}

A 40-year-old female with soft tissue lesion over the left hip region- HPE given as Liposarcoma
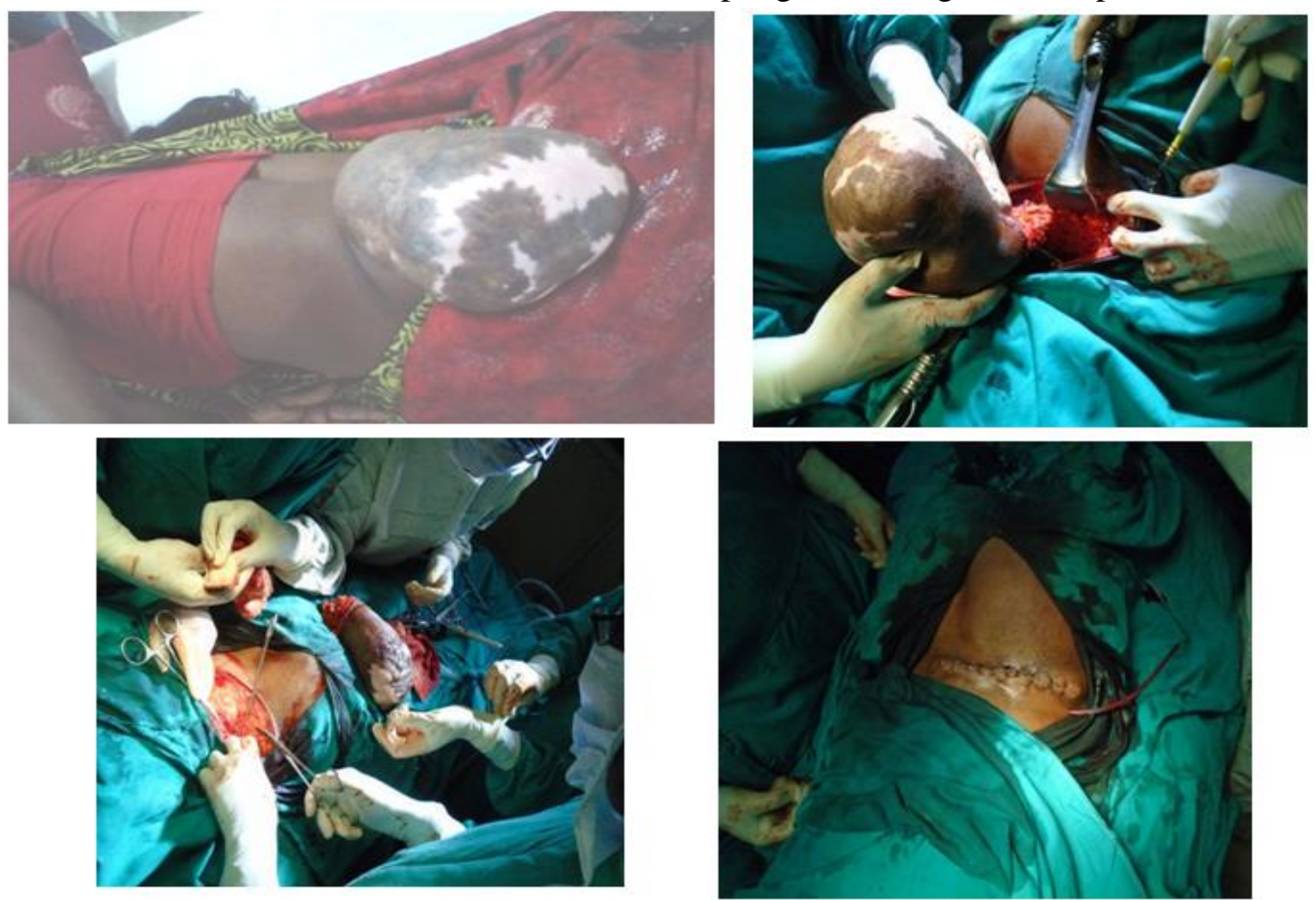


\section{JMSCR Vol||07||Issue\|10||Page 947-953||October}

\section{Case 5}

38-years male with soft tissue tumor over the lateral aspect of the right knee- HPE report is a malignant peripheral nerve sheath tumor.
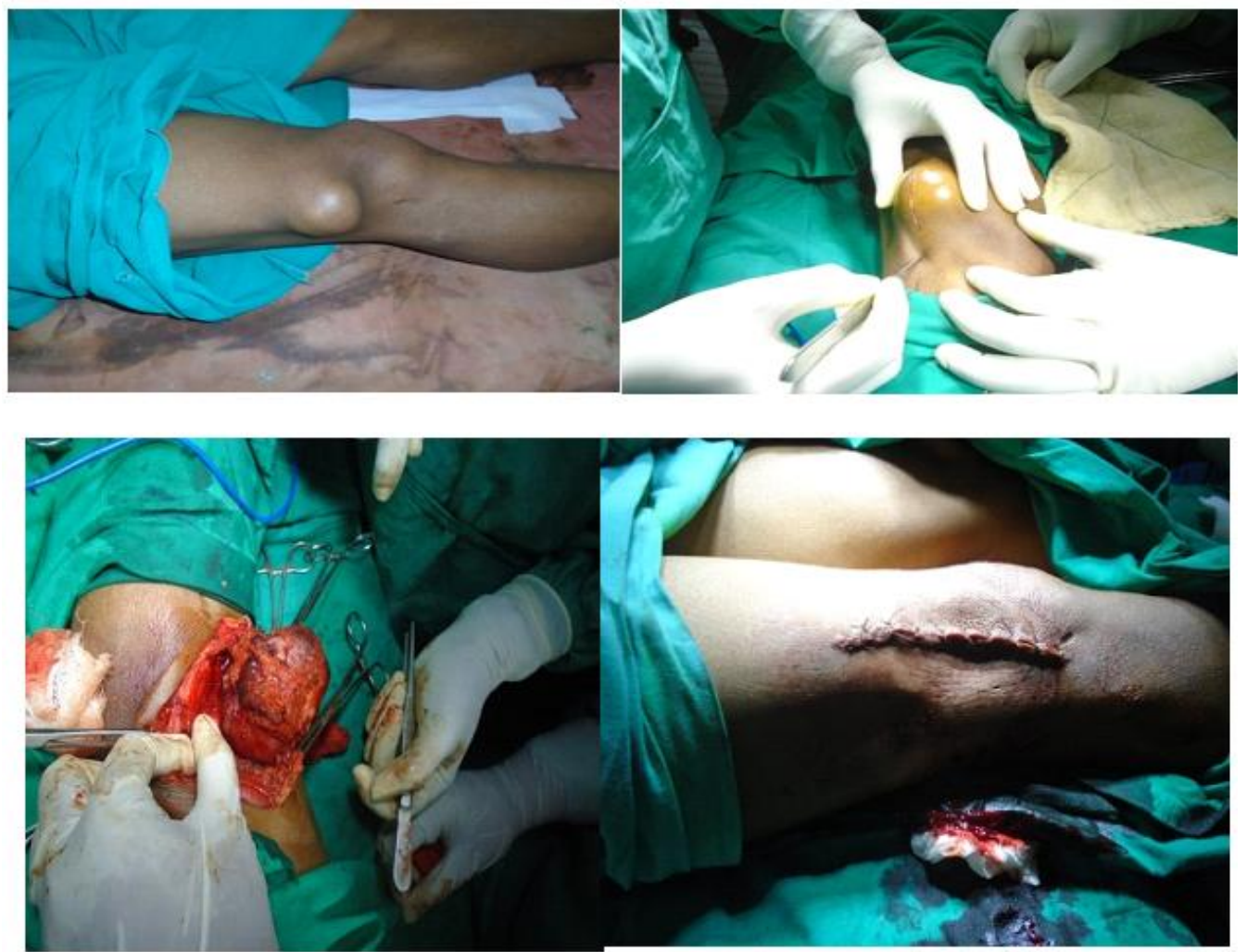

\section{Case 6}

A 38 year male with swelling over anterior abdominal wall-HPE is Dermatofibrosarcoma.
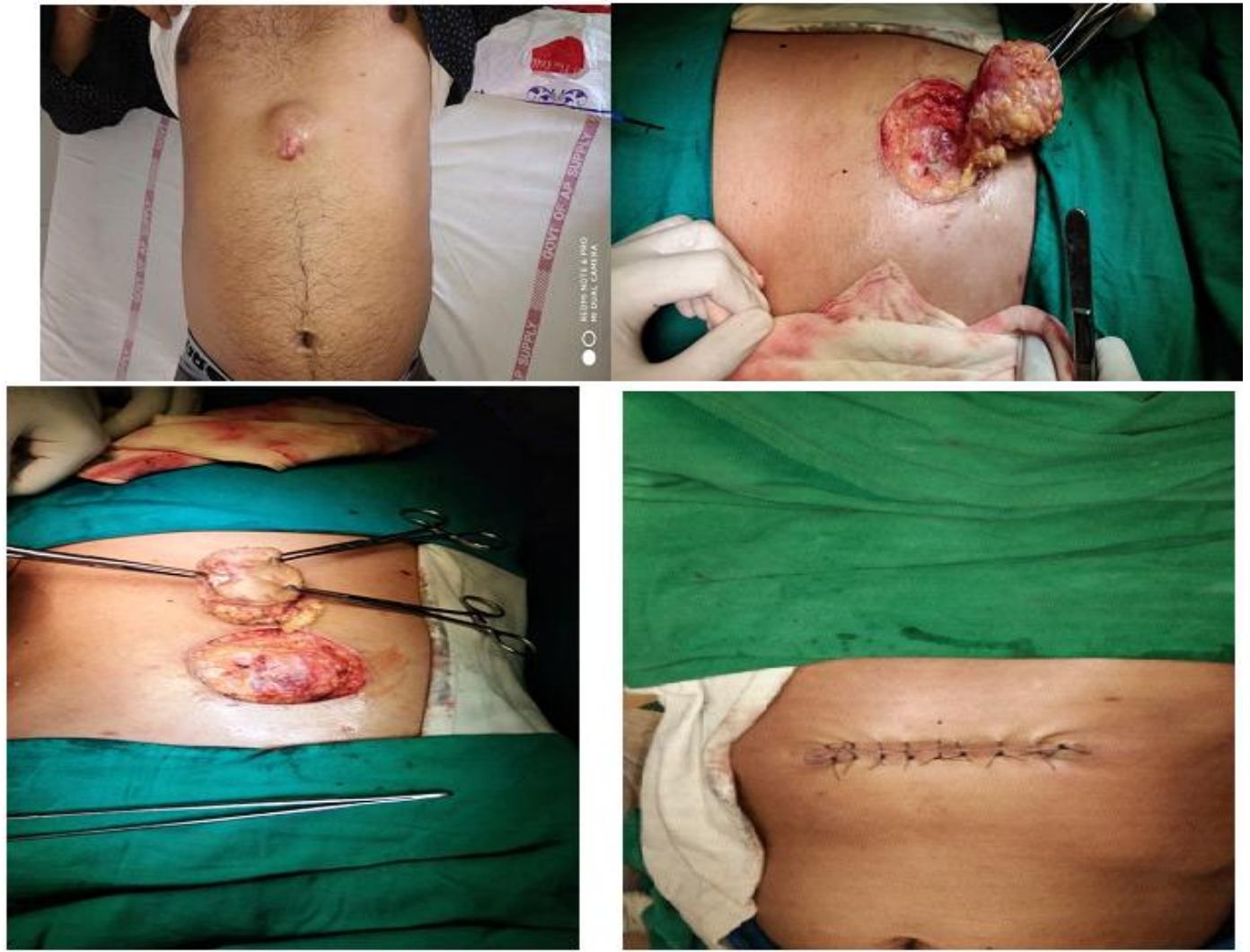


\section{Discussion}

\section{Incidence}

In adults, Liposarcoma and Malignant fibrous histiocytoma are common, followed by Rhabdomyosarcoma.

In children, rhabdomyosarcoma is common.

\section{Etiology}

1) Genetic: von Recklinghausen disease, Gardners syndrome, tuberous sclerosis, LiFraumeni syndrome, Gorlin's syndrome.

2) Chemicals: PVC, Tetrachlorodibenzodioxin, arsenic

3) Viral: HIV, CMV

4) Ionizing radiation

5) Lymphangio-sarcoma in carcinoma breast with postop. Lymphedema

6) Osteogenic sarcoma in Paget's disease of bone and radium exposure

\section{Clinical Features}

$\checkmark$ Painless swelling of short duration with a progressive increase in size sometimes with compression of adjacent structures.

$\checkmark$ Smooth, firm/hard, warm, and vascular.

$\checkmark$ No reliable findings to differentiate benign and malignant swellings.

$\checkmark$ So we have a suspicion of malignancy in any soft tissue mass when it is deep to deep fascia, mass $>5 \mathrm{~cm}$, very fast-growing newly found mass.

\section{Investigations}

$\checkmark$ For tissue diagnosis: incisional biopsy, TRUCUT BIOPSY.

$\checkmark$ For the extent of the tumor-MRI, CECT, MRA, USG

$\checkmark$ For metastatic workup-Chest X-ray, CECT chest, abdomen, and pelvis, USG, PET, or INTEGRATED PET.

$\checkmark$ Other investigations-GALLIUM-67 scintigraphy, FDG-PET, FISH, immunohistochemistry, tumor markers.

Staging: based on

TNM staging $\checkmark$ AJCC 2010/UICC staging of soft tissue sarcomas.

\section{Grading}

$\checkmark$ The Grade is the single most important factor in staging.

\section{Treatment}

$\checkmark$ Surgery: Enneking classification of surgical procedures. Different levels of amputations.

$\checkmark$ Radiotherapy- pre-operative, postoperative, palliative external radiotherapy.

$\checkmark$ Chemotherapy- neoadjuvant chemotherapy and postoperative chemotherapy.

\section{Prognostic Factors in Soft Tissue Sarcomas}

$\checkmark$ Size $>5 \mathrm{~cm}$

$\checkmark$ High grade

$\checkmark$ More than one compartment involved

$\checkmark$ Deep tumors and multicentric

$\checkmark$ Neurovascular invasion

$\checkmark$ Lung secondaries

$\checkmark$ Clearance margin

\section{Conclusion}

- In our study, soft tissue sarcomas are more common in middle-aged males. The most common anatomical site is the lower limb.

- In our study, the most common histopathological types are Malignant Fibrous histiocytoma and Liposarcoma.

- Surgery followed by adjuvant radiotherapy is the main modality of treatment as there are only two recurrence cases seen in our six months of follow up.

\section{References}

1. Bailey and love $27^{\text {th }}$ edition, 2018, edited by Norman. S. Williams, P. Ronan O' Connell, Andrew W. McCaskie.

2. SABISTON textbook of surgery, The biological basis of modern surgical practice, $20^{\mathrm{TH}}$ EDITION, by Elsevier, 2017

3. Fischer's Mastery of Surgery $7^{\text {th }}$ edition, 2019 
4. De Vita, Hellman, and Rosenberg'sCancer Principles and Practice of Oncology.

5. Bone and joint 360, vol.5, No.2, Extremity soft tissue sarcomas:what's hot and what's not-by M.S. Patel, N.C. Eastley, R.U. Ashford.

6. The journal of bone and joint surgery, British vol.92-B, no.11 Earlier diagnosis of bone and soft tissue tumours-by R.J. Grimer and T.W.R. Briggs.

7. O'Donnell PW, Griffin AM, Edward WC, et al. The effect of the setting of positive surgical margin in soft tissue sarcomas. 